\title{
PEMULIHAN EKONOMI INDONESIA PASCA PANDEMI COVID-19 DENGAN MENGKOMBINASIKAN MODEL FILANTROPI ISLAM DAN NDEAS MODEL
}

\author{
Yulia Puspitasari Gobel \\ Fakultas Ekonomi dan Bisnis Islam, IAIN Sultan Amai Gorontalo \\ Email : yuliapuspitasarigobel@iaingorontalo.ac.id
}

\begin{abstract}
ABSTRAK
Penelitian ini merumuskan model pemulihan ekonomi Indonesia pasca pandemi Covid-19 dengan mengkombinasikan model filantropi Islam dengan The National Domestic Economic AutoSustainability Model (NDEAS-MODEL). Metode penelitian ini berupa Studi Kepustakaan (Library Research). Hasil penelitian ini berupa gabungan antara filantropi Islam dengan NDEAS Model yang memberikan model keberlanjutan berupa kebangkitan ekonomi yang ditandai dengan adanya kenaikan pendapatan dan Negara Indonesia menjadi lebih hemat pengeluaran sehingga produktivitas lebih tinggi maka pendapatan dan tabungan juga dapat meningkat secara bersamaan, hal inilah yang dapat menekan biaya produksi karena investasi sama dengan tabungan, menghasilkan lapangan pekerjaan dan menarik investor domestik dan internasional, ketahanan pangan dan identitas negara serta berkurangnya pencemaran lingkungan.
\end{abstract}

Kata kunci : Pemulihan Ekonomi, Filantropi Islam, NDEAS-Model, Covid-19.

\begin{abstract}
This study formulates a model of Indonesia's economic recovery after the Covid-19 pandemic by combining the Islamic Philanthropy model with The National Domestic Economic Auto-Sustainability Model (NDEAS-MODEL), this research method is in the form of a Library Research, the results of this research are a combination of philanthropy Islam with the NDEAS Model which provides a sustainable model in the form of an economic revival marked by an increase in income and the State of Indonesia to be more efficient in spending so that productivity is higher, income and savings can also increase simultaneously, this is what can reduce production costs because investment equals savings, generate jobs and attract domestic and international investors, food security and national identity and reduce environmental pollution.
\end{abstract}

Keywords : Economic Recovery, Islamic Philanthropy, NDEAS-Model, Covid-19. 


\section{PENDAHULUAN}

Sejak pertama kali muncul penyakit coronavirus di kota China Wuhan akhir tahun 2019, telah menyebar ke 185 negara dan wilayah yang menginfeksi lebih dari 4.254 .800 orang dan membunuh lebih dari 287.293 orang secara global. Untuk membendung penyebaran virus lebih lanjut, pihak berwenang di seluruh dunia menerapkan langkah-langkah untuk mengunci negara dan kota pada tingkat yang berbeda-beda. Itu termasuk menutup perbatasan, menutup sekolah dan tempat kerja, dan membatasi pertemuan besar. Pembatasanpembatasan tersebut dikenal dengan istilah "Great Lockdown," membuat banyak kegiatan ekonomi global terhenti dan merugikan bisnis yang mengakibatkan Jumlah Pengangguran Meningkat, Industri jasa terpuruk dan Aktivitas manufaktur menurun.

Dalam kajian teori ilmu ekonomi, physical distancing atau pengetatan dan pembatasan aktifitas masyarakat akan berakibat pada penurunan agregat supply dalam perekonomian yang berdampak pada penurunan jumlah produksi. Kondisi dimana masyarakat yang hanya berdiam diri di rumah (stay at home), berdasarkan hukum Penawaran dan permintaan, lambat laun akan menyebabkan penurunan permintaan secara agregat yang berujung pada jumlah produksi yang terus menurun. Proses penurunan perekonomian yang berantai ini bukan hanya akan menimbukan guncangan pada fundamental ekonomi riil, melainkan juga merusak kelancaran mekanisme pasar antara permintaan dan penawaran untuk dapat berjalan normal dan seimbang. Mengingat bahwa aspek-aspek vital ekonomi yaitu supply, demand dan supply-chain telah terganggu, maka dampak krisis akan dirasakan secara merata ke seluruh lapisan atau tingkatan masyarakat. Berhubung ketahanan setiap lapisan atau tingkatan tersebut berbeda- beda, maka masyarakat ekonomi golongan menengah ke bawah khususnya mikro dan pekerja informal berpendapatan harian, tentu menjadi kelompok yang paling rentan terkena dampaknya.

Dampak di sektor riil tersebut kemudian akan menjalar ke sektor keuangan yang tertekan (distress) karena sejumlah besar investee akan mengalami kesulitan pembayaran kepada investornya. Pandemi ini memiliki efek buruk yang parah pada karyawan, pelanggan, rantai pasokan dan pasar keuangan, secara singkat, sebagian besar akan menyebabkan resesi ekonomi global. Namun demikian, karena pandemi ini tidak dapat diprediksi dan belum menunjukkan kepastian dari berakhirnya, diperlukan waktu bagi ekonomi dunia untuk pulih dari kondisi ini, sehingga pandemi ini akan mengarah pada perubahan permanen dalam dunia dan politiknya, terutama di bidang kesehatan, keamanan, perdagangan, pekerjaan, pertanian, produksi barang dan kebijakan sains. Karena dunia baru ini mungkin memberikan peluang besar bagi beberapa negara yang tidak mendominasi produksi dunia sebelumnya yang mengharuskan pemerintah untuk mengembangkan strategi baru dalam menyesuaikan tatanan ini tanpa banyak penundaan. (Açikgöz \& Günay, 2020)

Kegiatan ekonomi pada masa pandemi Covid-19 telah menyebabkan banyak lembaga memangkas perkiraan pertumbuhan mereka terhadap ekonomi global. Untuk Indonesia sendiri, Menteri Keuangan, Sri Mulyani Indrawati memprediksi pertumbuhan ekonomi dalam skenario terburuk bisa mencapai minus $0,4 \%$. Sementara itu, secara keseluruhan pertumbuhan komponen penerimaan Pajak hingga akhir bulan Maret 2020 masih bersumber dari pajak atas konsumsi rumah tangga, meskipun penerimaan pajak juga masih dibayangi tekanan akibat tren pelemahan industri 
manufaktur dan aktivitas perdagangan internasional, serta pelemahan aktivitas ekonomi akibat penyebaran Covid-19. Kemudian, seiring adanya aturan terkait Work From Home (WFH) baik untuk sektor pemerintah maupun sektor swasta, maka mulai terjadi perlambatan kegiatan usaha di akhir bulan Maret 2020 yang berpotensi menurunkan penyerahan dalam negeri yang kemudian akan menekan penerimaan Pajak Pertambahan Nilai Dalam Negeri (PPN DN) di bulan April 2020. Kondisi tersebut kemungkinan akan berlanjut dan semakin terkontraksi di bulan Mei, mengingat di bulan April sebagian daerah sudah melaksanakan Pembatasan Sosial Berskala Besar (PSBB) di beberapa wilayah terdampak. Sejalan dengan penerapan WFH dan PSBB tersebut, Pemerintah memberikan fasilitas perpajakan berupa relaksasi pembayaran $\mathrm{PPh}$ Pasal 29 OP dan pelaporan SPT PPh OP, yang mana berimbas pada belum optimalnya realisasi penerimaan $\mathrm{PPh}$ Pasal 29 OP.

Jumlah penduduk Indonesia yang bekerja di bidang informal dan kasual ada sebesar 74 juta jiwa atau 57.2\% sedangkan jumlah penduduk yang memiliki pekerjaan rentan berjumlah $46.68 \%$ atau 60 juta jiwa dari keseluruhan tenaga kerja di Indonesia. Mereka yang hidup di bawah garis kemiskinan masih sebesar 25 juta jiwa atau 9.4\% dari seluruh penduduk Indonesia (BPS, 2020) dan diekspektasikan akan terus bertambah dikarenakan kasus COVID-19 ini. Dengan mengasumsikan faktor lain konstan, maka akan ada pertambahan jumlah penduduk miskin sebesar 134.822 orang pada kondisi ringan di 20 wilayah yang memberlakukan PSBB. Tambahan penduduk miskin tertinggi terjadi di Kabupaten Bogor yaitu sebanyak 20.850 orang, diikuti dengan Provinsi DKI Jakarta sebesar 19.255 orang. Sedangkan wilayah dengan tambahan penduduk miskin terendah adalah Kota Tarakan yaitu sebesar 16.907 orang. Selisih persentase angka kemiskinan terbesar dialami oleh Kabupaten Bandung Barat sebesar 0,50\% sehingga angka kemiskinan pada kondisi ringan menjadi $9,81 \%$, tertinggi di antara sembilan belas wilayah lain. Untuk persentase angka kemiskinan terendah dalam kondisi ringan akibat pandemi COVID-19 jatuh kepada Kota Tangerang Selatan dengan angka kemiskinan sebesar $1,73 \%$ (Baznas, 2020).

Pada kondisi berat, posisi keparahan kemiskinan tidak berbeda pada kondisi ringan. Kabupaten Bogor masih menjadi wilayah dengan tambahan penduduk miskin tertinggi sebesar 134.038 orang dan diikuti dengan Provinsi DKI Jakarta sebanyak 123.779 orang. Ini menyebabkan persentase angka kemiskinan naik drastis dibandingkan pada September 2019. Persentase angka kemiskinan Kabupaten Bogor pada kondisi berat menjadi $8,87 \%$, naik sebanyak 226 basis poin dan Provinsi DKI Jakarta menjadi $4,59 \%$ yang sebelumnya $3,42 \%$. Kemudian, Kota Tarakan masih menjadi wilayah dengan pertambahan penduduk miskin terkecil sebanyak 5.485 orang. Persentase angka kemiskinan tertinggi pada dua puluh wilayah PSBB masih ditempati oleh Kabupaten Bandung Barat pada kondisi berat sebesar $12,50 \%$, sedangkan Kota Tangerang Selatan menjadi wilayah dengan angka kemiskinan terkecil sebesar $2,21 \%$. Total tambahan penduduk miskin pada kondisi berat di kedua puluh wilayah PSBB adalah 866.713 orang (Baznas, 2020)

Keanggotaan Indonesia sebagai salah satu negara dalam The Group of Twenty (G-20) Finance Ministers and Central Bank Governors mempunyai peluang besar untuk merefleksikan kepentingan Indonesia khususnya dibidang ekonomi (Sushanti, 2019) Dengan adanya kekuatan Indonesia sebagai negara dengan mayoritas 
penduduk muslim sebanyak $87 \%$ dari total populasi penduduk Indonesia yaitu 258 juta jiwanya. Optimisme proses globalisasi terhadap pandangan antara pemikiran barat dan Islam dapat terakomodasi dengan masuknya Indonesia sebagai anggota G20, hal ini akan memberikan dampak positif bagi pertumbuhan ekonomi dunia, yang selanjutnya mendorong Indonesia untuk terus melangkah maju dalam mengaktualisasikan diri pada pertumbuhan dan perkembangan ekonomi dunia. Menjadi anggota tetap dalam forum G20 membuka akses Indonesia dalam menstimulasi perekonomian dunia. Berangkat dari pengalaman turun naik situasi ekonomi yang telah dilalui Indonesia, tentunya akan membuat negara ini menjadi lebih cermat dalam merumuskan kerangka pemikiran bagi ekonomi dunia mealui forum G20.

Indonesia memiliki kepentingan yang lebih erat dalam mendorong koordinasi kebijakan antara negara-negara keanggotaan G-20, guna menuju pemulihan dan menjaga terciptanya sistem perekonomian global yang kuat, berkelanjutan, dan seimbang. Sebagai negara dengan populasi muslim terbesar di dunia, umat Islam dapat memberikan peran terbaiknya melalui berbagai bentuk atau model filantropi dalam Ekonomi dan Keuangan Syariah, Islamisasi ekonomi tidak bisa berdiri sendiri tanpa Islamisasi setiap muslim dan Islamisasi masyarakat. Seperti Islamisasi suatu masyarakat diwujudkan dengan organisasi keluarga Muslim, Islamisasi ekonomi dapat diwujudkan dengan meningkatkan jumlah ekonom yang memiliki pengetahuan syariah (Abdurrahman \& Yatoo, 2020). Peran ini diharapkan dapat mengatasi guncangan ekonomi yang terjadi dan seluruh masyarakat, khususnya umat muslim, dapat ikut serta berkontribusi dalam memulihkan guncangan tersebut.
Sedangkan strategi yang dilakukan oleh Negara China dalam mengembalikan perekonomian negaranya melalui model rekonstruksi pasca Wuhan COVID-19 yang disebut "The National Domestic Economic Auto-Sustainability Model (NDEAS-Model)." NDEAS-Model mengusulkan empat platform ekonomi, yakni (a) platform standardisasi pendidikan dan pelatihan teknis dalam negeri (P1); (b) platform infrastruktur dan transportasi produktif domestik (P2); (c) platform perdagangan strategis, investasi, dan perlindungan selektif (P3); (d) platform pengelolaan sumber daya alam dan lingkungan (P4). Tujuan utama NDEAS-Model adalah untuk menghindari penyakit pandemi masif yang diimpor, platform ketahanan pangan yang tidak berkelanjutan dan lemah, dan pengalihan pekerjaan (Ruiz Estrada, 2020).

Berdasarkan latar belakang tersebut, perlu dilakukan penelitian dampak pandemi Covid-19 pada perekonomian nasional, Beberapa sumber baik cetak maupun elektronik telah melaporkan tentang konsekuensi ekonomi pada masa pandemi Covid-19 tetapi sejauh ini, belum ada penelitian yang menganalisis konsekuensi potensial dari pandemi pada perekonomi nasional dalam bentuk penelitian. Selain itu, penelitian ini bertujuan untuk merumuskan suatu formulasi pemulihan ekonomi nasional pasca pandemi melalui kolaborasi antara model filantropi Islam dan model NDEAS yang dapat menstabilkan kondisi perekonomian Indonesia.

\section{TINJAUAN PUSTAKA}

NDEAS-Model (Ruiz Estrada, 2020) adalah skema ekonomi domestik dan tetangga yang adil dan harmonis. Ini didasarkan pada interaksi antara serangkaian platform ekonomi. Lebih tepatnya, implementasi model keberlanjutan otomatis ekonomi domestik domestik (NDEAS-Model) melibatkan 
penerapan dan koordinasi serangkaian platform ekonomi dengan implikasi sosial dan ekonomi pada prioritas yang berbeda masing-masing serta penerapan sosioekonomi baru. Model pembangunan untuk menggantikan integrasi ekonomi global melalui kerangka kerja globalisasi dengan pembangunan ekonomi domestik yang lebih kuat di bawah kerangka kerja deglobalisasi. Interaksi ini didasarkan pada empat platform ekonomi:

\section{Platform (P1) Standardisasi Pendidikan dan Pelatihan Teknis Dalam Negeri}

Program ini menggunakan kerangka kerja tindakan untuk menciptakan sumber daya manusia domestik berkualitas tinggi berdasarkan standardisasi pendidikan dan pelatihan di tingkat nasional. Dalam platform ini, kerangka kerja tindakan digunakan untuk membakukan pendidikan domestik di negara tersebut dan untuk secara bersamaan menciptakan kondisi untuk menghasilkan pekerja rumah tangga yang sangat berkualitas dengan produktivitas dan daya saing yang tinggi. Kelompok sumber daya manusia yang cakap ini pada gilirannya menghasilkan barang dan jasa dengan nilai tambah tinggi yang bersaing dengan baik di pasar domestik dan internasional, serta berfungsi sebagai alat utama untuk mengurangi pengangguran dan penciptaan lapangan kerja. Ada empat kegiatan domestik utama dalam program ini, yaitu: (i) pendidikan gratis untuk meningkatkan tingkat pendidikan dasar mereka; (ii) koordinasi dan standardisasi program sekolah dasar dan sekolah menengah dalam negeri; (iii) pengembangan program pelatihan teknis dalam negeri; (iv) menyiapkan jaringan informasi universitas nasional berdasarkan penelitian bersama dan proyek pengembangan yang memanfaatkan keempat kegiatan ini (Ruiz Estrada, 2005). Tujuan umum dari program ini adalah untuk meletakkan dasar pendidikan nasional yang kuat bagi generasi muda di negara ini sehingga mereka dapat bersaing di dalam negeri dan internasional.

Pada tingkat tersier, pengembangan program pelatihan teknis dalam negeri mencoba untuk bergabung dengan program akademik yang berbeda di bidang ilmiah yang berbeda melalui pertukaran program akademik di tingkat nasional termasuk pertukaran profesor dan ahli dan penelitian dan pengembangan bersama (R\&D) dalam berbagai bidang keilmuan bidang. Pertukaran profesor regional (dan ahli) di berbagai bidang (untuk kursus singkat dan seminar) di semua tingkatan harus dilaksanakan. Pendekatan ini, disertai dengan beasiswa nasional di program Master dan Doktor di seluruh dunia, bersama dengan penelitian dan pengembangan bersama $(R \& D)$ antara universitas di negara yang sama adalah lebih mungkin untuk bertemu dengan kesuksesan. Pendekatan ini harus dilengkapi dengan tawaran beasiswa pascasarjana nasional di antara universitas di negara yang sama.

Berkenaan dengan pelatihan teknis nasional, program ini mengusulkan strategi bersama untuk koordinasi dan standardisasi pelatihan nasional di berbagai sektor seperti pertanian, industri, dan jasa yang akan ditempatkan di bawah lingkup lembaga teknis nasional dan fakultas teknik universitas di negara tersebut. Sementara itu, platform teknologi informasi nasional harus dianggap sebagai dasar dari pengembangan pendidikan nasional, mengingat hal itu penting untuk pertukaran informasi dalam upaya koordinasi dan standardisasi program pendidikan dan pelatihan teknis ini. Ini memiliki tanggung jawab untuk mengoordinasikan semua program menggunakan pertukaran informasi di berbagai tingkatan berdasarkan pada program standardisasi pelatihan pendidikan dan teknis. 


\section{Platform Infrastruktur dan Transportasi Produktif Domestik (P2)}

Bagian ini mempertimbangkan dua jenis infrastruktur dan sistem transportasi dalam infrastruktur publik domestik dan transportasi dan infrastruktur swasta domestik dan transportasi. Khususnya memperhatikan dua jenis infrastruktur dan sistem transportasi di negara-negara dengan anggaran terbatas untuk infrastruktur. Ini karena kurangnya infrastruktur dan sistem transportasi menciptakan siklus kemiskinan yang konstan menurut penelitian ini dan dengan demikian menghambat pertumbuhan produksi nasional dan pengembangan manusia domestik di negara yang bersangkutan.

Tujuan umum dari program infrastruktur dan transportasi domestik bersama ini antara publik dan swasta adalah untuk mendapatkan dukungan finansial dari organisasi teknis dan keuangan regional. Organisasi-organisasi ini dapat membantu mengembangkan infrastruktur regional yang lebih baik dalam negosiasi bilateral atau regional. Dalam hal ini, platform ini berfungsi sebagai panduan untuk mengembangkan proposal mega proyek infrastruktur dan transportasi domestik untuk mendapatkan kredit dari berbagai organisasi keuangan regional.

Infrastruktur sosial domestik dan sistem transportasi bertujuan untuk mempromosikan upaya-upaya yang berkaitan dengan kesejahteraan sosial seperti persediaan bantuan rumah sakit pada saat terjadi bencana alam, epidemi, sistem transportasi umum, penyediaan sekolah dan universitas, serta pemasangan infrastruktur keamanan nasional seperti sebagai kantor polisi, markas militer, dan stasiun pemadam kebakaran. Semua upaya ini dapat secara signifikan berfungsi sebagai basis untuk pembangunan ekonomi di negara mana pun yang bersangkutan: kondisi sosial ekonomi domestik yang menguntungkan yang dihasilkan dari peningkatan infrastruktur sosial domestik dan sistem transportasi di masing-masing negara untuk mengurangi kerentanannya. Aspek lain dari platform infrastruktur produktif dan sistem transportasi mengacu pada layanan komunikasi, transportasi publik, kerjasama infrastruktur fisik (jembatan, jalan raya, kereta api, bandara, dan pelabuhan).

\section{Platform Perdagangan Selektif, Investasi, dan Perlindungan Pariwisata (P3)}

Program ketiga NDEAS-Model adalah perdagangan selektif strategis, investasi, dan platform perlindungan pariwisata (P3). Tujuan umum platform ini adalah untuk memusatkan upaya di negara mana saja dan negara tetangga untuk menciptakan platform yang lebih kuat untuk mempromosikan perdagangan, investasi, dan pariwisata di tingkat intratetangga.

Lebih khusus lagi, NDEAS-Model ini berupaya memperluas produksi dan ekspor nasional negara mana pun di pasar tetangga yang berbeda berdasarkan peningkatan produktivitas dan daya saing domestik, serta untuk menarik investasi langsung daerah (RDI) dan wisatawan dari berbagai negara tetangga. Platform ini juga dapat tertarik untuk melindungi ketahanan pangan strategis dan sektor manufaktur jika terjadi perang, pandemi, dan keadaan darurat nasional.

Upaya yang diadopsi untuk tujuan di atas termasuk: klasifikasi semua item makanan pokok dan sektor manufaktur untuk membangun platform ketahanan pangan yang kuat. Dengan berpartisipasi dan mendukung sejumlah besar produsen kecil dan menengah secara teknis dan finansial, semua bahan makanan pokok akan mudah diidentifikasi dan diorganisir sesuai dengan daftar prioritas pangan 
nasional. Ini pada gilirannya memungkinkan mereka untuk menghasilkan cukup dalam keadaan darurat nasional seperti kasus pandemi besar. Ini juga menjadi lebih mudah bagi orang menemukan stok makanan kapan saja dan di mana saja. Sebagai akibat dari hal di atas, semua produsen kecil dan menengah yang berpartisipasi dalam platform ini memiliki peluang yang sama untuk bersaing.

\section{Platform Pengelolaan Sumber Daya Alam dan Lingkungan (P4)}

Platform pengelolaan sumber daya alam dan lingkungan (P4) adalah platform keempat dalam Model-NDEAS. Gagasan utama dari modul ini adalah mencari solusi untuk berbagai masalah dalam pengelolaan dan perencanaan sumber daya alam dan lingkungan di negara mana pun. Fokus modul ini adalah prosedur administrasi, kerangka hukum, dan organisasi kelembagaan untuk membantu meningkatkan lingkungan dan penggunaan bencana alam masingmasing.

Selain itu, diusulkan di sini bahwa pusat-pusat litbang khusus didirikan untuk memberikan konsultasi dan saran untuk menyelesaikan masalah apa pun yang berkaitan dengan pengelolaan lingkungan dan bencana alam. Setidaknya ada tiga kategori R\&D dengan pusatnya masingmasing: (i) informasi dan pendidikan tentang lingkungan, (ii) penciptaan platform publik, hukum dan kelembagaan pro-lingkungan dan pengelolaan sumber daya alam, (iii) teknologi baru untuk mendapatkan manfaat pengelolaan lingkungan dan sumber daya alam.

\section{METODE PENELITIAN}

Pendekatan dalam penelitian ini berupa Studi Kepustakaan (Library Research) yang merupakan studi dalam mengumpulkan informasi dan data dengan bantuan berbagai macam material yang ada di perpustakaan seperti dokumen, buku, majalah. Studi kepustakaan juga dapat berasal dari buku referensi serta hasil penelitian-penelitian terdahulu sejenis yang berguna untuk mendapatkan landasan teori mengenai masalah yang akan diteliti dengan teknik pengumpulan data dengan melakukan penelaahan terhadap buku, literatur, catatan, serta berbagai laporan yang berkaitan dengan masalah yang ingin dipecahkan atau suatu kajian teoritis, referensi serta literatur ilmiah lainnya yang berkaitan dengan budaya, nilai dan norma yang berkembang pada situasi sosial yang diteliti. (Mirzaqon \& Purwoko, 2018)

$\begin{array}{llr}\text { Penelitian } & \text { dengan metode } \\ \text { kepustakaan ini digunakan untuk }\end{array}$ menyusun konsep kolaborasi model filantropi islam dan NDEAS Model untuk pemulihan ekonomi nasional pasca Covid19. Adapun langkah-langkah dalam penelitian kepustakaan menurut (Mirzaqon \& Purwoko, 2018) sebagai berikut : (a) Pemilihan topik Eksplorasi informasi (c) Menentukan fokus penelitian (d) Pengumpulan sumber data (5) Persiapan penyajian data (6) Penyusunan laporan

Sumber data yang menjadi bahan akan penelitian ini berupa buku, jurnal dan situs internet yang terkait dengan model filantropi Islam dan NDEAS Model.

Penelitian ini menggunakan tekhnik pengumpulan data melalui dokumentasi dengan menelaah dan/atau mengekplorasi beberapa Jurnal, buku, dan dokumen-dokumen (baik yang berbentuk cetak maupun elektronik) serta sumbersumber data dan atau informasi lainnya yang dianggap relevan dengan penelitian atau kajian (Supriyadi, 2017).

Teknik analisis data yang digunakan dalam penelitian ini adalah metode analisis isi (Content Analysis). Analisis konten secara luas terdiri dari tiga jenis. Dalam tipe pertama, yang 
mayoritas, orientasi kuantitatif dari metode ini ditekankan. Tipe kedua, dimana referensi kedalam dimensi kuantitatif sengaja dihindari, tidak mengandung referensi eksplisit kedalam dimensi kualitatif juga. Dalam jenis ketiga, baik dimensi subyektif dan metode kualitatif dinyatakan dengan berani atau orientasi kualitatif dan kuantitatif metode ditampung, sementara lebih condong ke arah pendekatan interpretatif. Pada titik ini, meskipun saya menyebutkan beberapa definisi penting dari jenis pertama dan kedua untuk tujuan perbandingan, penelitian ini menggunakan jenis ketiga karena definisi mencerminkan aspek kualitatif dari analisis konten (Devi Prasad, 2019)

\section{HASIL DAN PEMBAHASAN}

\section{Model Filantropi Islam}

Konseptualisasi dari praktik pelayanan (service), memberi (giving) dan asosiasi (association) yang secara sukarela membantu pihak lain yang membutuhkan sebagai ekspresi rasa cinta kepada sesama manusia. Islam sebagai agama yang syāmil dan kāmil serta rahmatan lil'alamin yang mencerminkan agama yang berwajah filantropis. Wujud filantropi ini digali dari doktrin keagamaan yang bersumber dari al-Qur'an dan Hadits yang dimodifikasi dengan perantara mekanisme ijtihad sehingga institusi zakat, infak, sedekah, dan wakaf muncul. Tujuannya adalah supaya harta itu jangan hanya beredar di antara orangorang kaya saja (Kholis et al., 2013).

Untuk menjamin kesejahteraan warga negara, negara perlu ikut campur dalam urusan ekonomi. Penghapusan bunga, pendirian lembaga Zakat dan Shadaqah, alokasi sumber daya ekonomi yang tepat, mencegah penimbunan, konsep Halal dan Haram dan kesejahteraan individu dan masyarakat adalah fitur yang membedakan sistem ekonomi Islam (Ali, 2014).
Berdasarkan (Mardiantari, 2019) Bantuan modal usaha bergulir berupa pemberian kambing ini dapat menjadi sebuah solusi yang efektif bagi para mustahik untuk dapat meningkatkan kesejahteraan hidupnya. Sebab dengan bantuan ini masyarakat akan mendapatkan keuntungan dan ini akan memberikan motifasi kepada para mustahik untuk berusaha keras. Keberhasilan yang diperoleh lembaga zakat, infaq dan sedeqah di Indonesia telah memberikan citra yang positif bagi lembaga-lembaga tersebut yang secara tidak langsung penilaian tersebut akan mengarah pada kontribusi ekonomi syariah terhadap perkembangan perekonomian di Indonesia.

Lembaga zakat, infaq dan sedekah di Indonesia telah banyak dipercaya oleh mitra baik perseorangan, lembaga atau perusahaan (nasional dan daerah) serta mendapat apresiasi positif dari PBB (United Nations) dalam programprogramnya yang banyak mendukung Millenium Development Goals (MDGs) dalam rangka pengentasan kemiskinan (Andriyanto, 2011). Sustainable Development Goals (SDGs) dirancang sebagai kelanjutan dari Milineum Development Goals (MDGs) yang belum tercapai tujuannya samapai pada akhir tahun 2015. SDGs adalah suatu rencana aksi untuk umat manusia, planet dan kemakmuran. Juga tujuannya untuk memperkuat perdamaian universal dalam kebebasan yang luas selain itu untuk mengatasi kemiskinan yang ekstrim adalah tantangan global yang paling besar dan merupakan prasyarat yang tidak dapat dilanjutkan untuk pembangunan berkelanjutan, Adapun tiga pilar yang menjadi indikator dalam konsep pengembangan SDGs yaitu, pertama indikator yang melekat pembangunan manusia (Human Development), di antaranya pendidikan, kesehatan. Indikator kedua yang melekat pada 
lingkungan kecilnya (Social Economic Development), seperti ketersediaan sarana dan prasarana lingkungan, serta pertumbuhan ekonomi. Sementara itu, indikator ketiga melekat pada lingkungan yang lebih besar (Environmental Development), berupa ketersediaan sumber daya alam dan kualitas lingkungan yang baik. (Wahyuningsih, 2018)

Zakat adalah ibadah maaliyah ijtima'iyyah, artinya ibadah dibidang harta yang memiliki kedudukan yang sangat penting dalam pembangunan masyarakat. Jika zakat dikelola dengan baik, baik pengambilan maupun pendistribusiannya dengan menerapkan fungsi-fungsi manajemen modern, insya Allah akan dapat mengangkat kesejahteraan masyarakat. Karena itu di dalam al-qur'an dan hadis, banyak perintah untuk berzakat, sekaligus pujian bagi yang melakukannya, baik didunia ini maupun di akhirat nanti. Sebaliknya, banyak pula ayat Al-qur'an dan Hadis Nabi yang mencela orang yang enggan melakukannya, sekaligus ancaman duniawi dan ukhrawi bagi mereka. Olehnya itu perlunya pengelolaan zakat secara profesional oleh lembaga yang dipercaya dan dikelola oleh pengelola zakat (amil) yang amanah, jujur, dan professional (Jasafat, 2015).

Sistem ekonomi dan keuangan zakat, infak, dan sedekah, tampak memiliki rancangan yang luar biasa hebat, cermat, dan akurat dalam menetapkan calon sasaran/target penerima dana zakat yang lazim dikenal dengan sebutan delapan kelompok sosial penerima zakat (tsamâniyah ashnâf al-mustahiqqîn), yakni: (1) fuqarâ', (2) masâkin, (3) 'âmilîn, (4) mu'allafah qulûbuhum, (5) riqâb, (6) ghârimîn, (7) sabîlillâh, (8) Ibn sabîl. Kelompok sosial penerima zakat ini termaktub dalam surah At-Taubah [9]: 103. Memerhatikan delapan kelompok sosial yang berhak menerima zakat di atas, sungguh luar biasa cermatnya, karena dengan pembagian delapan ashnâf ini, nyaris atau bahkan sama sekali tidak ada kelompok sosial yang terabaikan kesejahteraan sosial ekonominya. Karena, semua kelompok sosial dari berbagai kelas telah tertampung ke dalam delapan ashnâf ini. Bukan saja kaum fuqarâ' dan masâkin yang sangat diperhatikan oleh Alquran, akan tetapi juga kelompokkelompok sosial lainnya, dalam hal ini orang-orang yang terlilit utang, budakbudak dalam konteks sekarang kelompok sosial yang termapas kemerdekaan dirinya, kelompok orang-orang yang terjebak di perjalanan, dan bahkan juga lembaga sosisal kemasyarakatan yang bergerak dalam berbagai kepentingan umum tetap terjangkau melalui delapan kelompok mustahiqqîn ini. Tidak terkecuali mereka yang bergabung dalam hal pengurusan zakat itu sendiri yaitu kelompok âmilîn walau mereka terdiri atas orang-orang kaya sekalipun (Suma, 2015).

Sebagai lembaga sosial, organisasi pengelola zakat (OPZ) memiliki peran yang penting dan strategis untuk membantu pemerintah dalam menangani pandemi COVID-19. Pusat Kajian Strategis BAZNAS telah memaparkan landasan logis peran OPZ dalam merespon COVID-19 dan mengutarakan advokasi untuk kebijakan pendistribusian dan pendayagunaan OPZ yang relevan. Adapun OPZ yang berkolaborasi dengan Baznas dalam pencegahan Covid-19:

a) Rumah Zakat: Saluran Siaga (Hotline) COVID-19, Edukasi perilaku hidup bersih dan sehat (PHBS), Layanan penyemprotan Disinfektan, Bantuan Logistik dan Hygiene Kit, Dokumen Protokol Pencegahan Covid-19 dan Penerapan WFH

b) Lazismu: Saluran Siaga (Hotline) COVID-19, Edukasi perilaku hidup bersih dan sehat (PHBS), Layanan penyemprotan Disinfektan, Bantuan Logistik dan Hygiene Kit, Layanan 
Ambulance dan Faskes Siaga, Penyediaan Alat Pelindung diri (APD), Dokumen Protokol Pencegahan Covid19, Penerapan WFH, Layanan psikosional, Relawan Kesehatan khusus COVID-19 dan layanan jenazah.

c) Dompet Duafa: Saluran Siaga (Hotline) COVID-19, Edukasi perilaku hidup bersih dan sehat (PHBS), Layanan penyemprotan Disinfektan, Layanan Ambulance dan Faskes Siaga, Layanan psikosional, Relawan Kesehatan khusus COVID-19 dan layanan jenazah.

d) Dompet Sejuta Harapan: Saluran Siaga (Hotline) COVID-19 dan Bantuan Logistik dan Hygiene Kit.

e) Yatim Mandiri: Saluran Siaga (Hotline) COVID-19 dan Layanan penyemprotan Disinfektan.

f) Baznas RI: Saluran Siaga (Hotline) COVID-19, Edukasi perilaku hidup bersih dan sehat (PHBS), Layanan penyemprotan Disinfektan, Layanan Ambulance dan Faskes Siaga, Penyediaan Alat Pelindung diri (APD), dan layanan jenazah.

g) Laz Al ihsan Jawa Tengah: Saluran Siaga (Hotline) COVID-19 dan Bantuan Logistik dan Hygiene Kit.

h) Inisiatif Zakat Indonesia: Saluran Siaga (Hotline) COVID-19 dan Edukasi perilaku hidup bersih dan sehat (PHBS).

i) Yakesma: Saluran Siaga (Hotline) COVID-19, Edukasi perilaku hidup bersih dan sehat (PHBS), Layanan penyemprotan Disinfektan, Bantuan Logistik dan Hygiene Kit.

j) Bakrie Amanah: Saluran Siaga (Hotline) COVID-19, Edukasi perilaku hidup bersih dan sehat (PHBS), Layanan penyemprotan Disinfektan, Bantuan Logistik dan Hygiene Kit.

k) Solo Peduli: Saluran Siaga (Hotline) COVID-19, Edukasi perilaku hidup Layanan penyemprotan Disinfektan.
1) Wahdah Inspirasi Zakat: Saluran Siaga (Hotline) COVID-19, Edukasi perilaku hidup bersih dan sehat (PHBS), Dokumen Protokol Pencegahan Covid19.

m)Rumah Yatim: Saluran Siaga (Hotline) COVID-19, Edukasi perilaku hidup bersih dan sehat (PHBS), Layanan penyemprotan Disinfektan, Bantuan Logistik dan Hygiene Kit.

n) Sedekah Harian: Saluran Siaga (Hotline) COVID-19, Edukasi perilaku hidup bersih dan sehat (PHBS).

o) LAZ DPU Kaltim: Saluran Siaga (Hotline) COVID-19, Edukasi perilaku hidup bersih dan sehat (PHBS), Penerapan WFH.

p) Pusat Zakat Umat: Saluran Siaga (Hotline) COVID-19, Edukasi perilaku hidup bersih dan sehat (PHBS), Layanan penyemprotan Disinfektan, Bantuan Logistik dan Hygiene Kit, Penerapan WFH.

Hal tersebut dipublikasikan dalam dokumen policy brief edisi Februari 2020. Secara umum, dengan adanya COVID-19 yang telah berdampak negatif hampir pada seluruh aspek kehidupan, terutama ekonomi, maka telah banyak mustahik yang lahir di masa pandemi ini. Realita kehidupan di Indonesia, terutama di kotakota besar seperti Jakarta, dapat menjadi contoh terbaik bagaimana COVID-19 melemahkan ekonomi lokal dan mengganggu kehidupan sosial, dan bagaimana OPZ seperti BAZNAS, Dompet Dhuafa, dan yang lainnya, memberikan kontribusi yang adaptif untuk penanganan kemiskinan dan problematika sosial lainnya akibat COVID-19. Dalam hal ini peran zakat untuk penanganan COVID-19, hal ini dapat dikategorikan ke beberapa bidang. Di antaranya adalah bidang ekonomi, pendidikan, kemanusiaan, sosial, dan dakwah, dalam konteks mencegah penyebaran virus Covid-19 (Baznas, 2020). 


\section{Peran Zakat dalam Bidang Ekonomi}

Pengaruh COVID-19 terhadap ekonomi global telah dirasakan oleh pemerintah kita. Ini setidaknya dapat dilihat pasar saham Indonesia yang turun 1.9 persen per 7 Februari 2020. Deputi Gubernur Senior Bank Indonesia, Destry Damayanti bahkan mengatakan dampak COVID-19 tidak hanya berpotensi melemahkan sektor keuangan, tetapi juga sektor riil. Selain itu, ahli mengatakan COVID-19 akan memperlambat pertumbuhan ekonomi dunia, yang juga berdampak pada ekonomi Indonesia. Dampak COVID-19 pada melemahnya ekonomi dunia tentu akan membuka potensi lahirnya mustahik baru. Dalam konteks global, OPZ dapat bekerja sama dengan World Zakat Forum (WZF) untuk mendiskusikan peluang pendistribusian zakat untuk pencegahan, pengobatan, dan research vaksin COVID-19. Selain itu, bekerja sama dengan WZF, OPZ global dapat mengadvokasi peran zakat dalam menghadapi lemahnya ekonomi negaranegara WZF karena COVID-19. Dalam konteks nasional dan lokal, penyaluran dan pendistribusian zakat OPZ dalam bidang ekonomi dapat dikembangkan ke arah pemberdayaan mustahik baru yang disebabkan oleh lemahnya pertumbuhan ekonomi global karena COVID-19

\section{Peran Zakat dalam Pendidikan, Kemanusiaan dan Sosial}

Pandemi COVID-19 membuka peluang bagi OPZ untuk meluaskan perannya dalam bidang pendidikan, sosial dan kemanusiaan. Sebagai contoh, OPZ dapat mendistribusikan dana infaq untuk tindakan preventif dalam mencegah virus ini dari level individu, seperti yang telah dilaksanakan oleh banyak OPZ di awal pandemi ini ditemukan di Indonesia. Selanjutnya, kontribusi dalam bidang terkait juga telah dilakukan dengan membagikan masker (pelindung wajah) di tempat umum. Dalam peran spesifik di bidang pendidikan, OPZ telah banyak melakukan penyuluhan mengenai bahaya COVID-19. Ini telah banyak dilakukan, baik di internal OPZ ketika awal pandemi, maupun langsung terjun ke masyarakat umum, seperti mengunjungi sekolah, berkampanye dengan berkeliling menggunakan ambulans, dan lain sebagainya. Selain hal di atas, secara spesifik dalam bidang kemanusiaan, OPZ dengan WZF bekerja sama untuk melakukan kampanye global pentingnya mengonsumsi makanan halal, dengan mengacu kepada bukti-bukti ilmiah. Dalam konteks bekerja sama dengan WZF, BAZNAS telah melalui Ketua BAZNAS, Prof. Bambang Sudibyo, telah membuat seruan global peran zakat dalam menangani konsekuensi virus korona.

\section{Peran Zakat dalam Bidang Kesehatan}

Sebagaimana banyak diinfokan pada awal pandemi, bahwa belum ada vaksin khusus untuk COVID-19. Oleh karena itu, OPZ dapat bekerja sama dengan pemangku kesehatan terkait, baik itu di tingkat global maupun nasional, untuk memperluas perannya dalam mendukung studi terkait vaksin COVID19. Dalam praktiknya sejak pandemi muncul, OPZ yang memiliki unit kesehatan, seperti Rumah Sehat BAZNAS, dan Rumah Sehat Dompet Dhuafa, telah banyak berkontribusi melakukan penyuluhan kesehatan, terutama untuk kaum minoritas. Penyuluhan kesehatan yang dilakukan banyak memberikan informasi terkait bahasa COVID-19, penanganan untuk diri sendiri, dan gejalagejala terkait. Selain itu, Rumah Sehat Dompet Dhuafa dilaporkan menjadi salah satu rujukan untuk pasien positif COVID-19.

\section{Peran Zakat dalam Bidang Dakwah}

Informasi dari pihak berwenang menyatakan bahwa COVID-19 yang pertama kali ditemukan di Wuhan, China, ada kaitannya dengan pasar ikan laut dan 
hewan-hewan liar yang ada di daerah tersebut. Dalam kasus SARS-CoV dan MERS-CoV, telah dikonfirmasi virus tersebut berasal dari hewan. Oleh karena hal diatas, dalam konteks dakwah, OPZ dapat secara masif berkampanye pentingnya untuk mengonsumsi makanan halal dan thoyyib, terutama untuk menjaga diri dari virus-virus yang ada di hewanhewan yang tidak halal. Kampanye ini dapat dilakukan oleh divisi terkait di OPZ mengingat dakwah zakat tidak terbatas pada pentingnya membayar zakat. Akan tetapi, dakwah zakat dapat masuk ke seluruh aspek sosial.

Menurut (Abduh, 2019) Tiga Alat sosial keuangan Islam seperti infak, wakaf dan zakāt yang merupakan alternatif filantropi yang sangat baik untuk menutupi rata-rata kesenjangan investasi SDG global tahunan sebesar USD 2,5 triliun. Mendirikan dan mendanai laboratorium penelitian mutakhir, peningkatan gizi dan mencapai ketahanan pangan dari jangka pendek dan target jangka menengah merupakan area utama pemanfaatan dana. Negara untuk tidak bekerja secara individu tetapi bersamasama secara regional atau internasional dalam mencapai tujuan, khususnya untuk negara berkembang dan kurang berkembang yaitu saling berdampingan antara Negara berkembang dengan Negara kurang berkembang menuju kebangkitan pereonomian nasional dan internasional.

\section{Model NDEAS}

\section{Standarisasi Pendidikan dan Pelatihan Teknis Domestik (P1)}

Platform(P1) merupakan platform standardisasi pendidikan dan pelatihan teknis dalam negeri (P1) memiliki tujuan untuk meningkatkan permintaan dan penawaran tenaga kerja berkualifikasi domestik berdasarkan pada pengetahuan untuk meningkatkan produktivitas, tetapi juga menciptakan barang dan jasa baru dengan nilai tambah tinggi untuk dapat bersaing di pasar domestik dan tetangga. Ini didasarkan pada inovasi, strategi, dan rencana untuk menciptakan barang dan layanan baru untuk pasar domestik. P1 dapat menghasilkan lebih banyak pekerjaan (penciptaan lapangan kerja) dengan produktivitas tinggi. Perkembangan dari model P1 dapat menghasilkan kenaikan pendapatan dan Negara Indonesia menjadi lebih hemat pengeluaran sehingga produktivitas lebih tinggi maka pendapatan dan tabungan juga dapat meningkat secara bersamaan, hal inilah yang dapat menekan biaya produksi karena investasi sama dengan tabungan.

\section{Platform Infrastruktur dan Transportasi Produktif Domestik (P2)}

Platform ini menciptakan kondisi untuk pembentukan infrastruktur publik dan swasta dalam negeri dan sistem transportasi untuk mobilitas barang dan tenaga kerja di dalam negeri dan internasional (impor \& ekspor) dari negara mana pun. Infrastruktur publik dan swasta dalam negeri dan sistem transportasi dapat membantu meningkatkan produksi dalam negeri dan perdagangan internasional negara mana pun berdasarkan penerapan pelabuhan, bandara, jalan raya, kereta api, terowongan, dan jembatan yang lebih baik. (P2) memberikan peran yang lebih besar untuk menghasilkan pekerjaan dan menarik investor domestik dan internasional.

\section{Strategis Perdagangan Selektif, Investasi, dan Perlindungan Pariwisata Platform(P3)}

Dengan adanya citra internasional bagi Negara tetangga yang menjadi rujukan dalam perkembangan melalui platform P1 dan P2, program promosi di P3 semakin memperkuat perkembangan dengan menghasilkan dari pasar domestik dan dengan demikian menciptakan lebih banyak peluang bisnis di tingkat domestik 
dan tetangga. P3 didasarkan pada kerja sama di sektor swasta dan publik di negara yang sama. Suasana terbuka seperti itu yang diciptakan di tetangga memberikan peluang dan kondisi yang sama bagi semua produsen kecil dan menengah lokal dan produsen tetangga dalam semua aspek perdagangan, investasi, dan pariwisata. Ini dimanifestasikan dalam desain strategi umum dan adil untuk semua produsen kecil dan menengah lokal dilakukan secara efisien. Sehingga melalui P3, Negara Indonesia secara keseluruhan tidak hanya akan meningkatkan program ketahanan pangannya, tetapi juga identitas bersama sebagai negara yang mampu bertahan jika terjadi pandemi besarbesaran. Platform ini menuntut kolaborasi dan koordinasi dari kementerian industri dan perdagangan, eksportir (produk tradisional dan non-tradisional), kamar dagang, agen promosi pariwisata, kementerian pertanian, dan kementerian urusan luar negeri di negara yang sama.

\section{Platform Manajemen Sumber Daya Alam dan Lingkungan (P4),}

Platform manajemen sumber daya alam dan lingkungan (P4), bertujuan untuk mencari solusi untuk berbagai masalah yang dihadapi negara mana pun ketika mencoba mengurangi polusi dan pengelolaan alam yang lebih baik. Sumber daya melalui kontrol intensif secara kelembagaan dan hukum. Platform ini memperbaiki prosedur administrasi, kerangka hukum dan organisasi kelembagaan terkait dengan manajemen pengendalian pencemaran lingkungan yang lebih baik dan kebijakan prolingkungan.

\section{Model Keberlanjutan}

Model keberlanjutan dari filantropi Islam dan NDEAS Model menghasilkan solusi bagi perbaikan ekonomi Indonesia ditengah covid-19 maupun pasca covid19. Berikut model keberlanjutan dari perbaikan perekonomian, sebagai berikut:
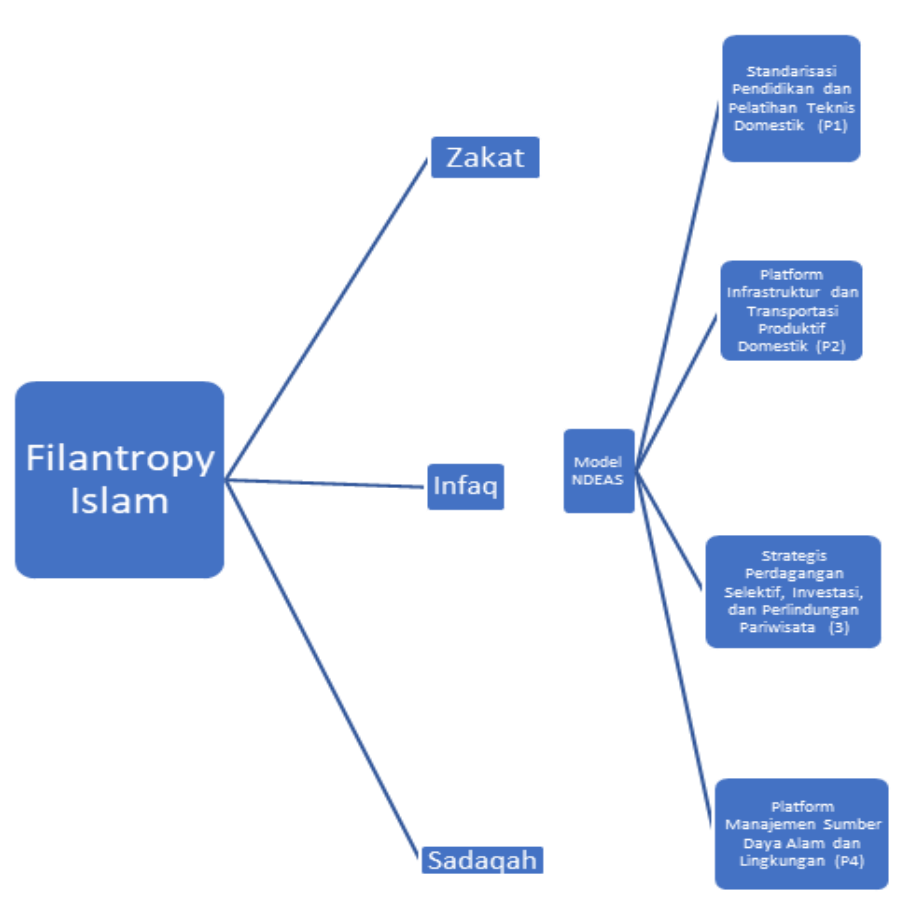

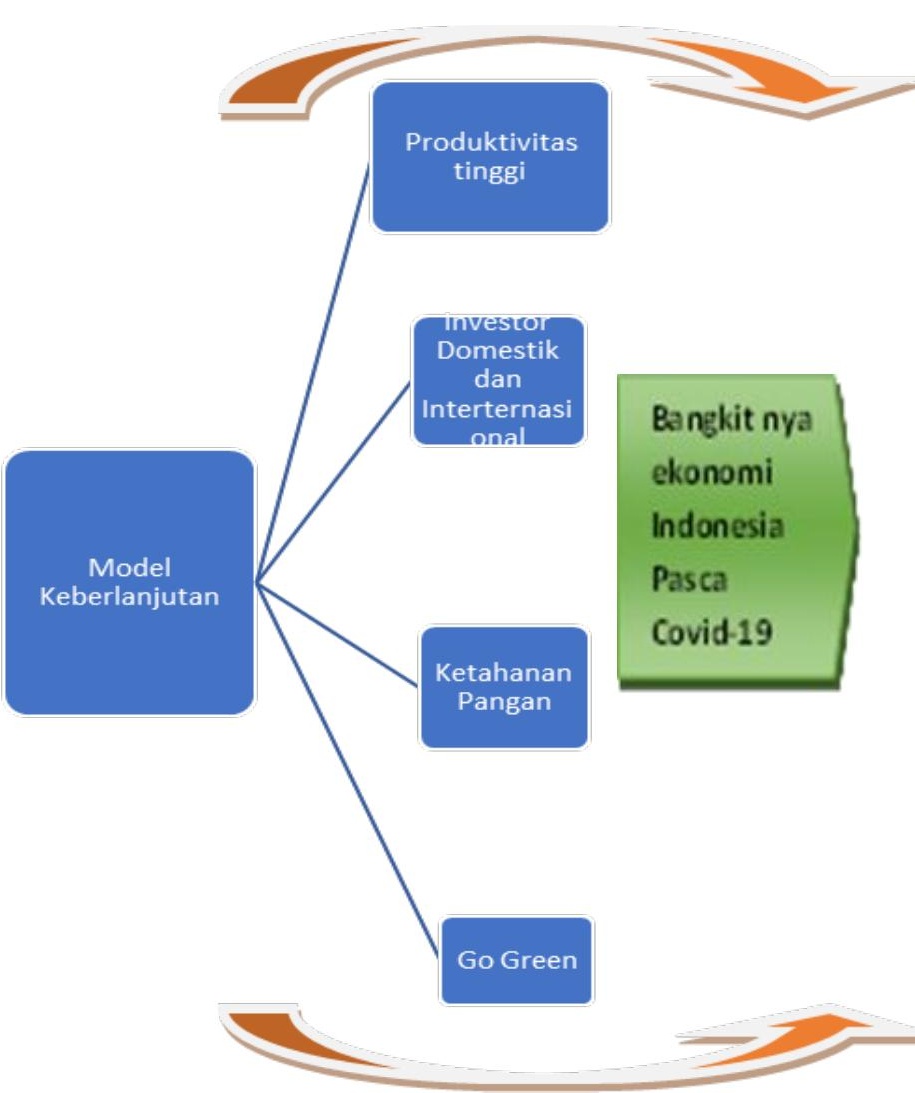

Gambar 1. Model keberlanjutan Ekonomi Pasca Covid-19 


\section{KESIMPULAN}

Platform yang ditawarkan melalui standardisasi pendidikan dan pelatihan teknis dalam negeri dapat menciptakan kekuatan dari dalam negeri yang selanjutnya menciptakan kondisi untuk pembentukan infrastruktur publik dan swasta dalam negeri dan sistem transportasi untuk mobilitas barang dan tenaga kerja di dalam negeri dan internasional (impor \& ekspor) dari negara mana pun. Serta memperkuat perkembangan pasar domestik sehingga menciptakan lebih banyak peluang bisnis di tingkat domestik dan tetangga. Selanjutnya melakukan kerja sama di sektor swasta dan publik di negara yang sama. Suasana terbuka seperti itu yang diciptakan di tetangga memberikan peluang dan kondisi yang sama bagi semua produsen kecil dan menengah lokal dan produsen tetangga dalam semua aspek perdagangan, investasi, dan pariwisata. Ini dimanifestasikan dalam desain strategi umum dan adil untuk semua produsen kecil dan menengah lokal dilakukan secara efisien yang pada akhirnya kerjasama antara dua negara berujuk pada penjagaan lingkungan hidup agar dapat memberikan rasa kenyamanan diantara dua negara.

\section{DAFTAR PUSTAKA}

Abduh, M. 2019. The Role Of Islamic Social Finance In Achieving $\mathrm{Sdg}$ Number 2: End Hunger, Achieve Food Security And Improved Nutrition And Promote Sustainable Agriculture. Al-Shajarah, (Special Issue Islamic Banking and Finance 2019), 185-206.

Abdurrahman, D., \& Yatoo, N. A. 2020. The Islamization of Economic Systems: A Methodological Approach. Al-Uqud: Journal of Islamic Economics, 4(28), 83-103.

Açikgöz, Ö., \& Günay, A. 2020. The Early Impact of the Covid-19
Pandemic on the Global and Turkish Economy. Turkish Journal of Medical Sciences, 50(3), 520-526.

Ali, A. 2014. Business Ethics in Islam. Edward Elgar Publishing.

Andriyanto, I. 2011. Strategi Pengelolaan Zakat Dalam Pengentasan Kemiskinan. Walisongo: Jurnal Penelitian Sosial Keagamaan, 19(1), 25-46.

Baznas. 2020. Laporan Baznas Dalam Penanganan Covid-19 (Vol. 3, Issue 2).

BPS. 2020. Keadaan Ketengakerjaan Indonesia. Februari 2020. No. 40/05/Th. XXIII, 05 Mei 2020

Devi Prasad, B. 2019. Qualitative content analysis: Why is it still a path less taken?. Forum Qualitative Sozialforschung, 20(3), 1-21.

Jasafat. 2015. Manajemen Pengelolaan Zakat, Infaq Dan Sadaqah Pada Baitul Mal Aceh Besar. Jurnal AlIjtimaiyyah, 3(2), 1-18.

Kholis, N., Sobaya, S., Andriansyah, Y., \& Iqbal, M. 2013. Potret Filantropi Islam Di Propinsi Daerah Istimewa Yogyakarta. La_Riba, 7(1), 61-84.

Mardiantari, Ani. 2019. Peranan Zakat, Infak Dan Sedekah (ZIS) Dalam Upaya Meningkatkan Perekonomian Masyarakat Kota Metro (Studi Pada Lazisnu Kota Metro). Diktum: Jurnal Syariah Dan Hukum, 17(1), 151-165.

Mirzaqon, A., \& Purwoko, B. 2018. Studi Kepustakaan Mengenai Landasan Teori Dan Praktik Konseling Expressive Writing Library. Jurnal BK UNESA, 8(1), 1-8.

Ruiz Estrada, M. A. 2020. A Post-WuhanCOVID-19 Economic Recovery Proposal: The National Domestic Economic Auto-Sustainability 
Model (NDEAS-Model). SSRN Electronic Journal, March. https://doi.org/10.2139/ssrn.355888 3

Suma, M. A. 2015. Zakat, Infak, dan Sedekah: Modal dan Model Ideal Pembangunan Ekonomi dan Keuangan Modern. Al-Iqtishad: Journal of Islamic Economics, 5(2). 524-274.

Supriyadi, S. 2017. Community of Practitioners: Solusi Alternatif Berbagi Pengetahuan antar Pustakawan. Lentera Pustaka: Jurnal Kajian Ilmu Perpustakaan, Informasi Dan Kearsipan, 2(2), 83093.

Sushanti, S. 2019. Aktualisasi Indonesia Dalam G20: Peluang Atau Tren?. Jurnal Ilmiah Widya Sosio politikaI, 1(1), 1-14.

Wahyuningsih, W. 2018. Millenium Develompent Goals (Mdgs) Dan Sustainable Development Goals (Sdgs) Dalam Kesejahteraan Sosial. Bisma : Jurnal Bisnis dan Manajemen, 11(3), 390-399. 